\title{
SOCIAL REPRESENTATIONS OF FAMILY AND VIOLENCE
}

\author{
Normélia Maria Freire Diniz ${ }^{1}$ \\ Maria de Fátima de Souza Santos ${ }^{2}$ \\ Regina Lúcia Mendonça Lopes ${ }^{3}$
}

Diniz NMF, Santos MFS, Lopes RLM. Social representations of family and violence. Rev Latino-am Enfermagem 2007 novembro-dezembro; 15(6):1184-9.

The idea of family alludes to relations of protection. Generally, the thought and idealized family connotes hegemony. In Brazil, adopting the idea of families would be more appropriate considering the ethnic and cultural multiplicity. However, it is in this refuge that generally involves relations between adults, youth and children, that domestic violence occurs, which is a social phenomenon of alarming relevance. This review article aimed to discuss the relation between social representations of family and violence in a space of family relations, from studies performed with various social groups composed of women and/or men, children, health professionals and health managers. Theses and dissertations, developed in the Federal Universities of Pernambuco and Bahia, Brazil, were used as the study base. The studies full reading was followed by a registration form. The results pointed the family as a moral value that makes difficulty breaking relations of violence. The existent paradigms in social and health areas that influence and establish professional actions, do not answer to the consideration of the phenomenon family violence.

DESCRIPTORS: family; family relations; violence

\section{REPRESENTACIONES SOCIAIS DE LA FAMILIA Y VIOLENCIA}

La idea de familia remete a las relaciones de protección. En general, la familia pensada e idealizada indica hegemonía. En Brasil, sería más apropiado volver natural la idea de familias, considerando la multiplicidad étnica y cultural. Aún así, es en este refugio que involucra las relaciones entre adultos, jóvenes y niños, que la violencia familiar ocurre, ganando tal fenómeno relevancia. Este artículo de revisión objetiva discutir la relación entre las representaciones sociales de familia y de violencia en el espacio de las relaciones familiares, basado en estudios realizados con grupos sociales diversos. Se tomó como base tesis y disertaciones de la Universidad Federal de Pernambuco y de la Universidad Federal de Bahia. La lectura integral de los estudios fue guiada por una ficha de registro. Los resultados apuntaron la familia como valor moral que influencia el rompimiento de las relaciones de violencia. Los paradigmas existentes en las áreas social y de salud, que influencian y determinan las acciones profesionales, no responden a la consideración del fenómeno de violencia familiar.

DESCRIPTORES: familia; relaciones familiares; violencia

\section{REPRESENTAÇÕES SOCIAIS DA FAMÍLIA E VIOLÊNCIA}

A idéia de família remete a relações de proteção. Em geral, a família pensada e idealizada denota hegemonia. No Brasil, seria mais apropriado naturalizar a idéia de famílias, considerando a multiplicidade étnico-cultural. No entanto, é nesse refúgio que envolve as relações entre adultos, jovens e crianças, que a violência familiar ocorre, ganhando tal fenômeno relevância. Este artigo de revisão objetiva discutir a relação entre representações sociais de família e de violência no espaço das relações familiares a partir de estudos realizados com grupos sociais diversos. Tomou-se como base tese e dissertações da Universidade Federal de Pernambuco e da Universidade Federal da Bahia. A leitura integral dos estudos foi acompanhada por uma ficha de registro. Os resultados apontaram a família como valor moral que dificulta o rompimento das relações de violência. Os paradigmas existentes nas áreas sociais e de saúde não respondem a consideração de fenômeno da violência familiar.

DESCRITORES: família; relações familiares; violência

${ }^{1}$ PhD in Nursing, Adjunct Professor Bahia Federal University, Brazil, e-mail: normelia@lognet.com.br; ${ }^{2}$ PhD in Psychology, Adjunct Professor Pernambuco Federal University, Brazil, e-mail: mfsantos@ufpe.br; ${ }^{3} \mathrm{PhD}$ in Nursing, Full Professor Bahia Federal University, Brazil, e-mail: reginalm@cpunet.com.br 


\section{INTRODUCTION}

"The family is the foundation of everything"(1). This categorical statement is the title of an article that resulted from answers, by several individuals, to questions asked by researchers during daily conversations. It presents the idea of family "as an affective and harmonious institution"; a place of protection, a notion that seems commonplace in society.

The family is considered a sanctuary in a heartless world ${ }^{(2)}$. It is the foundation of society: In short, it is an abstract, neat, nuclear and private institution $^{(3)}$. It appears that, in most societies, this is the idea and idealization of a family.

Some of the first questions that come up when referring to family include: What kind of family is that? From what period are they? What is their social status? What kind of culture do they belong to?

However, it is important to emphasize that the very idea of family is a social construct and the current family design, which nowadays seems natural, is neither the only existing nor the most "correct" one.

It is risky to consider the social relationship patterns we know as natural, because culture "is in the sequence of things for those who were born in it, and the sequence of things is created as imposing itself by a kind of immanent strength" ${ }^{\prime \prime}(4)$.

In our country ${ }^{(5)}$, therefore, it would be more appropriate to denaturalize the family concept and talk about "families, in the plural sense, considering the ethnic and cultural multiplicity that constitutes the base of the Brazilian demographic organization".

Therefore, the hegemonic idea of family still seems linked to the nuclear bourgeois family. From an academic point of view, "a standard family organization model, historically and anthropologically speaking, does not exist; there is no such a thing as a regular family ${ }^{(5)} *$. According to social representations, which have been part of the social imaginary, there seems to be only one "ideal" family pattern, even if that model is to be achieved at any cost.

If the family is regarded as a center of harmonious, convivial gathering for parents and children, a caring and protective setting, how can such family patterns be balanced with domestic violence?

The goal of this study is to discuss the relationship between social family patterns and violence in family settings, based on studies performed with different social groups, composed of women and/ or men, children, health professionals and health administrators.

Violence has been an everyday issue in the media, subject in small talks, and a source of concern for adults, young people and children alike. Being a multifaceted object per excellence, violence has challenged researchers, who strive to fit it into a specific, definite concept.

The definition of violence has been changing over the years, and taken different meanings in different settings. This is true whether it regards whoever is responsible for violent actions - an individual, an institution, or the State -no matter how the actions are performed - by one's own hands or following orders - or the way those actions happen including moral humiliation and homicide - or because of its meaning in different social groups.

As for violence against women, they are victims of domestic violence and carry that experience with them when they are attended at health services, which, in turn, is also a violent environment. Violence is not considered a health issue and, since this phenomenon has been settled, women get more and more exposed. It often goes by unnoticed by women and health professionals alike ${ }^{(6)}$.

For Social Psychology and the Theory of Social Representations (TSR), saying that violence is cultural is the same as conceiving it as a social object that brings up different representations that affect the creation of a given social reality.

In this context, where the symbolic and representative activity is taken as constitutive of social practice, the impact that social representations have on social practices needs to be acknowledged, whether they are violent or not. Therefore, it seems appropriate to study social violence representations as a complex system, where a number of social representations and practices interact.

Knowing the social representations of domestic violence will make it easier to understand this phenomenon, which so strongly affects people's health and also helps health professionals to come up with new ways to treat people who are in chronically violent situations and/or at risk.

This kind of study discloses the scientific knowledge about violence and family in a dissertation

* authors' italics 
and thesis layout in nursing and social service, arguing that the complexity of the topic needs to be researched on from different points of view.

\section{METHODS}

This work consists of six scientific studies from the Federal University of Pernambuco - UFPE and from the Federal University of Bahia - UFBA, presented from 2002 to 2005; they include one dissertation (from UFPE) and five theses, two of which (about nursing) are from UFBA and the other three (two about Social Service and one about Public Health) from UFPE.

This choice contemplates not only multidisciplinarity, but also scientific work from two universities in the Northeast.

As to the data source, an analysis was carried out on the referred studies, based on the final reports. The selection criterion was to be a study on domestic violence, using the Theory of Social Representations as technical support.

This situation permitted to analyze the theories created and shared by common sense about domestic violence in different social groups, composed of women and/or men, children, health professionals and health administrators.

The studies were analyzed with a view to social representations of family relations. Therefore, each report was registered on a form with the following information: type of violence, who the victims were; and the way violence was expressed in the family.

\section{RESULTS AND DISCUSSION}

Social representations of violence against women were discussed in a dissertation presented in the Doctoral Program in Social Service at the Federal University of Pernambuco(7). The author interviewed women from low social classes who were victims of domestic violence. Based on those interviews, social representations of men, women, marriage and violence were analyzed. Men, in general, are considered naturally** violent by the surveyed women, although they are considered the authority figure that is needed to preserve the family. The surveyed women stated that being a woman is associated to the concept of motherhood. There is a clear link between the idea of woman and mother, which leads to a hypothesis of a common aspect that creates a single mother-woman representation and goes beyond women's different experiences.

That social representation clearly shows that motherhood is still the basis for the representation of woman. This work highlights that not even the several changes in society and in women's lives over the last decades have been enough to separate women's from mothers' roles.

"The social representations that link woman and motherhood are examples of that chain of meanings founded on naturalizing convictions." ${ }^{\prime(8)}$

However, the surveyed women assure the stability of the family center through affective relationships with their children. Marriage was mostly represented by negative elements, including lack of respect, cheating, loneliness and violence, which break away from the ideal romantic love. Despite their negative family life experience in marriage, the interviewees stated their preference of living with violence over living alone. They reported the difficulties for a woman to live alone, the fear of losing the breadwinner, and, above all, the importance of keeping the family together. Family seemed a moral value that hinders breaking away from violence. They often stated that family is the base of everything.

Talking about domestic violence is talking about violent relationships among relatives or people we like. The victim can be a child, a teenager, an elderly person, male or female. That kind of violence happens among people who live in the same place, even though they are not relatives. For Santos ${ }^{(9)}$, although violence is often believed to be something that typically threatens individuals in a public place or on the street, it often occurs within the family domain.

Couples' representations about domestic violence during pregnancy were addressed in a Master's Thesis carried out at the Federal University of Bahia ${ }^{(10)}$. The social representation of man reported in the statements was that of [...] the provider of family needs. That is, the man is responsible for providing money for his home. The woman's identity, from the interviewees' perspective, is far from natural. It is previously constructed based on a social discourse that values female sweetness, fragility, intuition and sensitiveness.

* authors' italics 
Such qualities are typically feminine and, as such, unchangeable ${ }^{(7)}$.

When interviewing men who had a violent marital relationship ${ }^{(11)}$, it was observed that, most of the times, their violence was a representation of a perceived threat of losing power over their wives. For those men, their family was constructed based on the complete power that men must have over their wives, as a form of proving their masculinity. Men decide about what kind of friendship, clothes and jobs their wives can have. For the author, physical violence appears as an attempt to re-establish male power in the family. For men, fights in the family were entirely private and had the objective of re-establishing "regular" relationships within the family.

That kind of control is the result of a longterm social process through which concepts of power, domination, and strength are linked to masculinity as a unique male component. In the social imaginary, by extension, the concept of female weakness, sweetness and submission is created because they lack that virile component. It is the result of a labeling and inculcating social work, forming a social identity that everyone knows and recognizes, an identity that is designed in the social world ${ }^{(12)}$.

The same idea seems to occur in families where men have sexually abused their daughters. The study ${ }^{(13)}$ shows that, after filing a legal complaint against the man who abused his daughter, both the wife and the abused daughter wanted him to come back home and "re-establish the family". The surveyed men stated that the father figure completes the family.

The nuclear and neat family should be preserved. If the father figure is missing, the family is incomplete and threatened. Thinking about domestic violence is indeed thinking about a man and woman's uneven hierarchical relationships; however, it should be considered that family conceptions are subjacent to that relationship.

The study showed that social representations of domestic violence are not autonomous; they are deeply linked to hegemonic social representations of family and to the significance of a man's and a woman's role in the family. The results from different groups pointed at the homogeneity of male and female roles determining unequal power relationships. Together with those patterns, there is the idea of a nuclear family that justifies and authorizes violent relationships because it makes it more difficult to break away from the unequal relationships resulting from the "ideal family". This perpetuates violence across generations.

Health professionals seldom understand the way women victims of domestic violence think. In fact, they sometimes even blame women for their own hardship ${ }^{(14)}$. For those professionals, women stay with their husbands because they like being beaten and because of the economic power, and "[...] in health services, women are also exposed to violence" since the relationship between patients and health professionals is impersonal, hierarchical, professionals believe that women victims of violence do not want to end their own suffering.

The interviewed health professionals think that marital violence is private and, therefore, that they should not intervene. They think that other professionals should solve that problem, such as social workers, psychologists and the chief of police. Their work should be limited to taking care of the symptoms and injuries. These representations seem to indicate that, by limiting the health concept to the biological aspect only, those professionals trigger a new kind of violence: neglect and lack of investments in health education practices in order to prevent new violence episodes.

Some municipal health administrators ${ }^{(15)}$ considered domestic violence a matter of gender, social status or some male disorder. They showed some disagreement between the idea and the actions they proposed as managers, while their discourse was merely based on rules. However, they cannot come up with specific practices for women victimized by violence. The managers said that "[...] feminist women are the ones who demand actions for women and, specially, for women victims of violence. The demand for those actions is considered an issue of the Feminist Movement, and not as referring to a concern of the Public Health department or society."

Naturalizing the meanings ascribed to men and women is ingrained in the public space regarding health professionals' and administrators' roles when assisting people or when designing public health policies. Anchored in social constructs regarding gender, both professionals and managers consider domestic violence as a private problem or a disease that should be treated. Some actually blame women for their own hardship. When domestic violence is analyzed within the public domain, some see it as a consequence of economic inequality. Nonetheless, most of the times, health professionals believe that 
they only need to take care of the pathologies, and that other departments, such as Justice, should be responsible for solving the violence issue.

Although the studies include testimonials from several social groups, Brazilian statistical data - no matter where they are from, regardless of social class, gender or race - clearly show that women experience most domestic violence. It happens in family settings, paradoxically considered, from a social viewpoint, as privileged places of protection, love and companionship.

In this sense and, according to the studies, women experience most violence, regardless of the type (emotional, physical, sexual, symbolic, or institutional violence). Although violence is a public health problem, society insists on naturalizing violent relationships within the family. When health professionals and authorities state that domestic violence is a private matter, they leave out their professional and legal duties to protect abused people and contribute to perpetuate that kind of violence.

\section{FINAL CONSIDERATIONS}

The social and health paradigms that influence and determine professional actions avoid considering this phenomenon. In relation to the studies about

\section{REFERENCES}

1. Kaloustian SM. Família brasileira: a base de tudo. São Paulo (SP): Cortez; 2002.

2. Lasch C. Refúgio num mundo sem coração. A família: santuário ou instituição sitiada? Rio de Janeiro (RJ): Paz e Terra; 1997.

3. Santos MFS. A formação da identidade no espaço socializador da família. In: Arcoverde AMB. Mediação de Conflitos e Família. Recife (PE): Editora UFPE; 2002. p. 223-9.

4. Augé M. O sentido dos outros. Atualidade na Antropologia. Petrópolis (RJ): Vozes; 1999.

5. Neder G. Ajustando o foco das lentes: um novo olhar sobre a organização das famílias no Brasil. In: Kaloustian SM. Família brasileira: a base de tudo. São Paulo (SP): Cortez; 2004. p. 28-35. 6. Bourdieu P. A dominação masculina. Rio de Janeiro: Bertrand Brasil, 2003; 158 p.

7. Queiroz FM. Não se rima amor e dor. Representações sociais sobre a violência doméstica. [tese]. Recife (PE): Departamento de Serviço Social/UFPE; 2005.

8. Santos MFSS, Novelino AM, Nascimento, AP. O mito da maternidade: discurso tradicional sob roupagem modernizante? In: Moreira ASP. Representações sociais: teoria e prática. João Pessoa (PB): Editora UFPB - Autor Associado; 2001. p. 269-93. domestic violence and the Theory of Social Representation (TSR), the latter is an attempt to understand the social thinking developed throughout history in a specific society. Thus, the TSR can contribute to understand that phenomenon through an investigation of the meanings the subjects attributed to interpersonal relationships and a violent episode, as well as understanding how thinking patterns guide the actions and determine such practices in a specific society.

Severe consequences of violence include post-traumatic stress, a devastating effect of both family and political violence, triggered by the transformation of the victimizing protector into a violent individual $^{(16)}$.

The meanings stated by women in the everyday nursing work environment point out two different profiles of nursing workers: violence agents and violence receptors. This indicates educational actions as a coping strategy ${ }^{(17)}$.

Violence is a specific and historical social phenomenon and related to socioeconomic conditions; its roots and types are present in daily interpersonal relationships ${ }^{(18)}$. The scars each person bears, often clearly or subtly, remind of painfully violent situations $^{(19)}$ when compared to those of other individuals, and they entail harmful consequences for the person or his/her family.

9. Santos MFSS. Representações sociais e violência doméstica. In: Souza L, Trindade ZA. Violência e exclusão: convivendo com o paradoxo. São Paulo (SP): Casa do Psicólogo; 2004. p. 132-45.

10. Santana SBF. Representações de casais sobre violência doméstica na gravidez. [dissertação]. Salvador (BA): Escola de Enfermagem/UFBA; 2005.

11. Gomes NP. Violência conjugal: análise a partir da construção da identidade masculina. [dissertação]. Salvador (BA): Escola de Enfermagem/UFBA; 2003.

12. Diniz, NMF, Almeida MS, Lopes, RLM, Gesteira, SMA, Oliveira, JF. Mulher, saúde e violência: o espaço público e o privado. O Mundo da Saúde 1999 março-abril; 23(2):106-12. 13. Lima SLC. Representações sociais da violência conjugal contra a criança. [dissertação] Recife (PE): Departamento de Serviço Social/UFPE; 2003.

14. Bispo TCF. Representações sociais de profissionais de saúde acerca da assistência à mulher em situação de violência conjugal. [dissertação] Salvador (BA): Escola de Enfermagem/UFBA Ba; 2002.

15. Cruz MP. A saúde da mulher em situação de violência: o que pensam os gestores de gestoras municipais do Sistema Único de Saúde? [dissertação] Recife (PE): Programa Integrado de Saúde Coletiva/UFPE; 2002. 
16. Vendruscolo TS, Ribeiro MA, Armond LC, Almeida ECS, Ferriari MGC. As políticas sociais e a violência: uma proposta de Ribeirão Preto. Rev Latino-am Enfermagem 2004 maiojunho; 12(3):564-7.

17. Dias, HHZR, Ramos, FRS. O "des"cuidado em saúde: a violência no processo de trabalho em enfermagem. Texto Contexto Enfer 2003 janeiro-março; 12(1):44-51.

18. Sluzki, C. Violência familiar e violência política: implicações terapêuticas de um modelo geral. In: Sshnitman, DF. Novos paradigmas, cultura e subjetividade. Porto Alegre: Artes Médicas; 1996. p. 228-43.

19. Braz M, Cardoso MHCA. Em contato com a violência - os profissionais de saúde e seus pacientes vítimas de maus tratos. Rev Latino-am Enfermagem 2000 janeiro-fevereiro; 8(1):91-7. 